\title{
腎移植後高血圧の管理
}

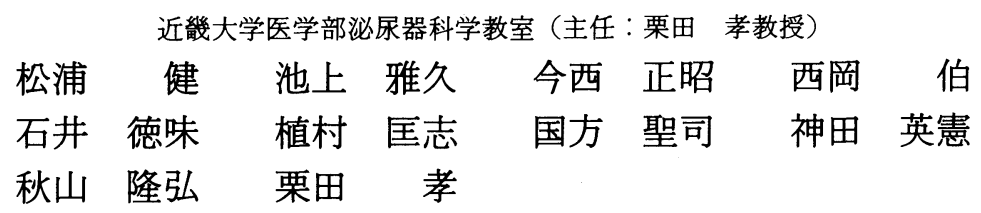

\section{MANAGEMENT OF HYPERTENSION AFTER RENAL TRANSPLANTATION}

\author{
Takeshi Matsuura, Masahisa Ikegami, Masaaki Imanishi, Tsukasa Nishioka, Tokumi Ishii, \\ Tadashi Uemura, Seiji Kunikata, Hidenori Kanda, \\ Takahiro Akiyama and Takashi Kurita \\ Deprtment of Urology, Kinki University School of Medicine
}

(Director: Prof. T. Kurita)

We report the clinical result of our management for post-transplant hypertension in 47 renal allograft recipients who were followed up for more than one year after transplantation. Hypertension developed in $4(26.7 \%)$ out of 15 cases who were treated with conventional immunosuppressive therapy (Group I) and 18 (56.3\%) out of 32 cases treated with CsA (Group II).

In group I, all the 6 patients who had been nephrectomized their original kidney at the time of transplantation did not develop hypertension. And the blood pressure before transplantation had a marked effect on post-transplant blood pressure. In group II, there were many recipients who had become hypertensive after transplantation though most of them became normotensive with dose reduction of immunosuppressants. Ten normotensive patients before transplantation who had not developed hypertension retained their normal blood pressure throughout the course without any antihypertensive medication.

We could find no correlation between graft function and blood pressure, although recipients with poor graft function had a tendency to be hypertensive.

A satisfactory fall in blood pressure in the patients treated with CsA was observed when the immunosuppressive regimen was changed to triple therapy to reduce the dose of CsA. The recorded blood pressure were $174.0 \pm 19.0 / 105.2 \pm 16.5 \mathrm{mmHg}$ after transplantation and 145.2 $\pm 15.7 / 78.4 \pm$ $17.1 \mathrm{mmHg}$ at the latest follow-up.

We performed original nephrectomy in 6 patients whose blood pressure could not have been controlled by the antihypertensive medication. All the venous sampling studies showed that increased renin secretion was confined to original kidneys. Original nephrectomy including bilateral transcatheter embolization in one case had a satisfaitory depressive effect making their blood pressure easily controllable.

In conclusion, because there are many factors affecting post-transplant hypertension we have to manage the patient in the most suitable strategy to him to prevent the adverse effect. We think it is the first step to give antihypertensives and reduce the dose of CsA. We should further examine the possibility of artery stenosis or original kidney involvement to perform proper management including dilatation of stenosis or original nephrectomy at a proper time.

Key words: renal transplantation, hypertension

\footnotetext{
要旨：腎移植後高血圧の管理法についてわれわれの経験した症例をもとに検討した結果を報告した。 CsA 非使用例（I 群）15例中 4 例（26.7\%），CsA 使用例（II群）32例中18例（56.3\%）に移植後高血圧 が発症した。
} 
I 群では移植時に固有腎摘をうけた症例が 6 例あり，これらは全例高血圧を発症せず，術前血生が移 植後血圧に反映される傾向を認めた。II群では後術高血圧の発症が多かったが，大部分の症例で免疫抑 制剂の減量により血圧が正常化した。術前血圧が正常で移植後も高血圧を発症しなかった10例では，全 経過を通じて降圧剂を必要としなかった。

I 群，II群とも移植腎機能と血圧に有意な相関を認めなかったが，機能不良例に高血圧が多くみられ る傾向があった。

II 群で免疫抑制剂投与量と血圧の関連を検討すると，高血圧例はCsA の減量により $174.0 \pm 19.0$ /

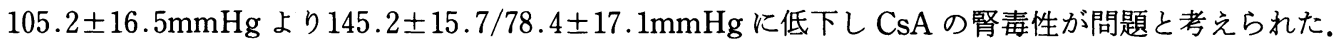

腎移植後, 降圧剂に反応せず高血圧が持続する 6 例に対し, 固有腎からのレニン分泌充進を確認後, 1 例の固有腎動脈塞栓術を含む固有腎摘除術を施行した。血圧は全例で十分にコントロール可能となり， 有効な治療法と考えられた。

腎移植後の高血圧は多様な要因が影響して発症し, 長期予後を考えると個々の症例に最適な治療を速 かに行ならべきと思われた。

キーワード：腎移植，高血圧

腎移植後の高血圧は種々の要因が複雑に作用して発 症し，その発症率は22 77\%で腎移植後の合併症のら ちでも比較的頻度の高いことはよく知られてい る(1) 5)．腎移植後高血圧が直ちに重篤な合併症を引き おこすことは少ないと思われるが，長期的には循環器 系や移植腎機能に拈よぼす悪影響を無視できず，的確 な治療が必要である，そこで，腎移植後高血圧のより 良い対処法，管理法を検討するため，われわれの経験 した症例をもとに，成因，治療法を考察した。

\section{対象および方法}

近畿大学医学部泌尿器科で1988年12月までに腎移植 を行ない， 1 年以上経過観察した 47 例を対象とした。 Cyclosporine (CsA) 非使用例（I 群：15例）とCsA 使用例（II 群：32例）に分類し, 移植前血圧, 固有腎 摘，移植腎機能，免疫抑制剂投与量などとの関連を検 討した。I 群，II群で生体腎（LD）はそれぞれ12例， 16例, 死体腎 $(\mathrm{CD})$ ： 3 例，16例，男性：10例，5 例, 女性：5 例，15例であった。平均年龄は I 群：28.7土 8.6 歳 (14 50歳), II 群：27.3土9.9歳 ( $9 \sim 56$ 歳), 平均観察期間は I 群：63.9土21.9力月（1年 8 力月 $\sim 9$ 年), II 群: $39.3 \pm 16.3$ 力月 ( 1 年 6 年) であっ た。

免疫抑制法は，I 群では azathioprine (AZ) または mizoribine (MZ) と prednisolone (Pred) の 2 鼡ある いは 3 剂を併用投与し, II 群では CsA と Pred の 2 剂 あるいは $\mathrm{AZ}, \mathrm{MZ}$ のどちらかを加えた 3 剤法で行 なった。急性拒絶反応の治療には methylprednisolone (MP), 抗ヒトリンパ球グロブリン (ALG), OKT3, 15-deoxyspergualin（DSG）を使用した。また，高血
圧症例に対する降圧剂は主にカルシウム拮抗剤, $\alpha, \beta$ 遮断剂を使用した。

\section{成}

\section{1. 移植後高血圧の頻度}

高血圧症を収縮期圧 $160 \mathrm{mmHg}$ 以上，あるいは払張 期圧 $95 \mathrm{mmHg}$ 以上と規定すると, 移植後約 6 力月の移 植腎機能安定時には I 群 4 例 (26.7\%), II 群18例 (56.3\%)が高血圧と判定された。II群で多く発症した が有意差（ $\chi^{2}$ 検定）は認められなかった。

\section{2. 術前血圧との関連}

I 群では術前高血圧や膀胱尿管逆流現象のため, 移 植時に固有腎摘を行なった症例が 6 例あり，あわせて 検討した（表 1 )。移植前高血圧症例 (HT) は 7 例, 正常血圧例 (NT) は 8 例であった。固有腎摘の効果は 明らかで, 高血圧発症例はみられなかった。固有腎摘 を行なわなかった症例では, 移植後高血圧は術前血圧 に影響されやすく，術前高血圧例は全例高血圧を発症

表 1 術前血圧・固有腎摘との関連 (CsA 非使用症例) A. 移植前高血圧症例： 7 例

\begin{tabular}{c|c|c}
\hline $\begin{array}{c}\text { 移植 時 } \\
\text { 固有腎摘 }\end{array}$ & $\begin{array}{c}\text { 移植後高血压 } \\
\text { (降圧剤使用) }\end{array}$ & 拒絶 \\
\hline$(+): 4$ 例 & $0(0)$ 例 & 1 例 \\
$(-): 3$ & $3(3)$ & 3 \\
\hline
\end{tabular}

B. 移植前正常血圧症例：8例

\begin{tabular}{|c|c|c|}
\hline $\begin{array}{l}\text { 䔟植 時 } \\
\text { 督摘 }\end{array}$ & $\begin{array}{l}\text { 䔟植後高血王 } \\
\text { (降圧剂使用) }\end{array}$ & 拒絶 \\
\hline $\begin{array}{l}(+): 2 \text { 例 } \\
(-): 6\end{array}$ & $\begin{array}{l}0(0) \text { 例 } \\
1(1)\end{array}$ & $\begin{array}{l}1 \text { 例 } \\
3\end{array}$ \\
\hline
\end{tabular}


表 2 術前血圧との関連 ( $\mathrm{CsA}$ 症例)

A. 移植前高血圧症例 : 13例

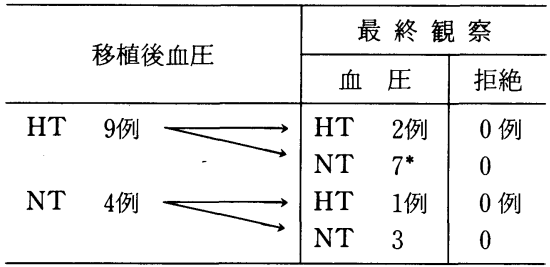

B. 移植前正常血圧症例：19例

\begin{tabular}{|c|c|c|c|c|}
\hline & \multirow{2}{*}{ 移植後血圧 } & \multicolumn{3}{|c|}{ 最 終 観 察 } \\
\hline & & 血 & 圧 & 拒絶 \\
\hline \multirow[t]{2}{*}{ HT } & 9例 $\longrightarrow$ & HT & 2例 & 0 例 \\
\hline & & & 7 & 2 \\
\hline \multirow[t]{2}{*}{ NT } & 10例 $\longrightarrow$ & HT & 0例 & 0 例 \\
\hline & & NT & $10^{* *}$ & 1 \\
\hline
\end{tabular}

表 3 移植腎機能の影響（CsA 非使用症例）

\begin{tabular}{|c|c|c|}
\hline 移植後血圧 & $\mathrm{Cr}<2.0 \mathrm{mg} / \mathrm{dl}$ & $\mathrm{Cr} \geqq 2.0 \mathrm{mg} / \mathrm{dl}$ \\
\hline HT & $\begin{array}{c}2 \text { 例** } \\
(22.2 \%)\end{array}$ & $\begin{array}{c}2 \text { 例 } \\
(33 . * * \\
(3 \%)\end{array}$ \\
\hline NT & $\begin{array}{c}7 \\
(77.8 \%)\end{array}$ & $\begin{array}{c}4 \\
(66.7 \%)\end{array}$ \\
\hline 計 & 9 例 & 6 例 \\
\hline
\end{tabular}

PRA (ng/ml/h)

(N.S.)

${ }^{*} 6.1,16.7$

${ }^{* *} 4.0, \quad 7.1$

表 4 移植腎機能の影響（CsA 症例）

\begin{tabular}{|c|c|c|}
\hline 移植後血圧 & $\mathrm{Cr}<2.0 \mathrm{mg} / \mathrm{dl}$ & $\mathrm{Cr} \geqq 2.0 \mathrm{mg} / \mathrm{dl}$ \\
\hline HT & $\begin{array}{c}2 \text { 2例* } \\
(8.7 \%)\end{array}$ & $\begin{array}{r}3 \text { 例** } \\
(33.3 \%)\end{array}$ \\
\hline NT & $\begin{array}{l}21 \\
(91.3 \%)\end{array}$ & $\begin{array}{c}6 \\
(66.7 \%)\end{array}$ \\
\hline 計 & 23例 & 9 例 \\
\hline
\end{tabular}

PRA (ng/ml/h)

(N.S.)

${ }^{*} 2.0,2.8$

${ }^{* *} 0.9, \quad 1.8, \quad 6.9$

した。術前正常血圧例 6 例中高血圧を発症したのは 1 例のみで, 術後も血圧が正常な 5 例のうち 4 例で降圧 剤は不要であった。 また，移植後高血圧例で移植腎機 能廃絶例が多くみられた。

II 群(表 2 )では $\mathrm{CD}$ 例が多く, 術前検查を十分に行 ならことは困難なため, 移植前に固有腎摘が行なわれ たのは 1 例であった。術前高血圧症例は術後も高血圧
表 5 免疫抑制剂使用量の影響 ( $\mathrm{CsA}$ 症例)

A. 高血圧発症例：18例

\begin{tabular}{l|r|r|c}
\hline & \multicolumn{1}{|c|}{ 移 植 後 } & \multicolumn{1}{c|}{ 最終観察 } & $\mathrm{p}$ \\
\hline 最高血圧 $(\mathrm{mmHg})$ & $174.0 \pm 19.0$ & $145.2 \pm 15.7$ & $<0.01$ \\
最低血圧 $(\mathrm{mmHg})$ & $105.2 \pm 16.5$ & $78.4 \pm 17.1$ & $<0.01$ \\
$\mathrm{CsA}(\mathrm{mg} / \mathrm{kg} /$ 日 $)$ & $4.6 \pm 0.7$ & $2.8 \pm 0.6$ & $<0.01$ \\
$\operatorname{Pred}(\mathrm{mg} /$ 日) & $10.0 \pm 2.1$ & $8.7 \pm 1.7$ & $<0.05$ \\
\hline \multicolumn{4}{|c}{ mean $\pm \mathrm{SD}$}
\end{tabular}

B：高血圧非発症例：14例

\begin{tabular}{|c|c|c|c|}
\hline & 移植 後 & 最終観察 & $\mathrm{p}$ \\
\hline 最高血圧 (mmHg) & $136.0 \pm 11.3$ & $123.0 \pm 12.1$ & $<0.01$ \\
\hline 最低血王 (mmHg) & $78.6 \pm 10.1$ & $63.7 \pm 15.4$ & $<0.01$ \\
\hline $\mathrm{CsA}(\mathrm{mg} / \mathrm{kg} /$ 日) & $4.3 \pm 1.2$ & $3.1 \pm 0.7$ & $<0.05$ \\
\hline $\operatorname{Pred}(m g / 日)$ & $8.8 \pm 1.9$ & $8.4 \pm 2.1$ & ns \\
\hline
\end{tabular}

表 6 腎提供者年齢

\begin{tabular}{|c|c|c|c|c|c|}
\hline \multirow{2}{*}{$\begin{array}{c}\text { 提供者年齢 } \\
\text { (歳) }\end{array}$} & \multicolumn{2}{|c|}{$\mathrm{I}: \mathrm{CsA}(-)$} & \multicolumn{2}{|c|}{ II $: \operatorname{CsA}(+)$} & \multirow{2}{*}{$\begin{array}{c}\text { 高血圧発症例 } \\
(\%)\end{array}$} \\
\hline & NT & $\mathrm{HT}$ & NT & HT & \\
\hline $10 \sim$ & 0 例 & 0 例 & 1 例 & 0 例 & 0 \\
\hline $20 \sim$ & 2 & 0 & 3 & 0 & 0 \\
\hline $30 \sim$ & 0 & 2 & 7 & 0 & 22.2 \\
\hline $40 \sim$ & 4 & 1 & 5 & 1 & 18.2 \\
\hline $50 \sim$ & 5 & 1 & 9 & 3 & 22.2 \\
\hline $60 \sim$ & 0 & 0 & 2 & 1 & 33.3 \\
\hline
\end{tabular}

の続くことが多く，4 例で固有腎摘を行ない血圧は正 常化した。 また，腎移植により血圧が正常化する症例 も認めた。II群では後前血圧が正常でも，移植後，降 圧剂投与にもかかわらず高血圧を発症する症例が多 かった。これらは，免度抑制剤の減量とともに血圧が 正常化する傾向を認めた。術前血圧が正常で術後も高 血圧を発症しなかった10例では，降圧剤は全く不要で あったＩII群の他の22例中，降圧剂不要例は固有腎摘 をらけた 1 例のみであった。

\section{3. 移植腎機能の影響（表 3, 表 4)}

I 群，II群とも移植腎機能と血圧に有意な相関はみ られなかったが $\left(\chi^{2}\right.$ 検定 $)$, 機能不良例に高血圧の頻度 がやや高かった。高血圧例の血浆レニン活性 (plasma renin activity：PRA）は I 群では全例高値であった が，II群では特別の傾向を示さなかった。

\section{4. 免度抑制剂投与量}

II 群で検討した結果を表 5 に示す，統計処理は $\mathrm{t}$ 検 定で行なった，移植後の血圧は高血圧発症例，非発症 例とも最終観察時には有意に低下した。特に，高血圧 
表 7 固有腎摘除術施行症例

\begin{tabular}{|c|c|c|c|c|c|c|c|c|}
\hline \multirow{2}{*}{ 症 例 } & \multicolumn{2}{|c|}{ 術 } & 前 & \multicolumn{3}{|c|}{ 術 } & \multirow{2}{*}{ 予後 } & \multirow{2}{*}{$\mathrm{Cr}$} \\
\hline & CsA & 血圧 & PRA & 血圧 & PRA & 降圧剂 & & \\
\hline 1. $\begin{array}{l}\mathrm{LD} 7 \\
16 \mathrm{M}\end{array}$ & - & $152 / 118$ & 4.0 & $124 / 84$ & 3.6 & + & 拒絶 & - \\
\hline 2. $\begin{array}{l}\mathrm{LD} 28 \\
24 \mathrm{M}\end{array}$ & + & $200 / 120$ & 10.9 & $134 / 62$ & 8.6 & + & 生着 & 5.6 \\
\hline 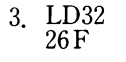 & + & $218 / 120$ & 6.3 & $128 / 64$ & 6.5 & + & 生着 & 1.2 \\
\hline $\begin{array}{l}\text { 4. }{ }_{37 \mathrm{M}}^{\mathrm{CD} 11} \\
\text { 37 }\end{array}$ & + & $198 / 120$ & 6.7 & $148 / 62$ & 0.9 & + & 生着 & 1.9 \\
\hline 5. $\begin{array}{l}\mathrm{CD} 14 \\
28 \mathrm{M}\end{array}$ & + & $186 / 100$ & 2.2 & $158 / 72$ & 1.0 & - & 生着 & 1.4 \\
\hline 6. ${ }_{36 \mathrm{M}}^{\mathrm{CD} 17^{*}}$ & + & $184 / 100$ & 13.4 & $136 / 78$ & 0.8 & + & 生着 & 2.5 \\
\hline
\end{tabular}

発症例の平均值は正常範囲にまで低下したが, 降圧剤 が不要となった症例は 1 例のみであった。この時の免 疫抑制剂投与量を比較すると, 最終観察時には高血圧 発症例で CsA および Pred 量が，また高血圧非発症例 では CsA 量が有意に少なかった。

\section{5. 腎提供者年齢（表 6 ）}

最終観察時の高血圧症例を提供者の年齢別に検討し た. 20 歳以下では高血圧の発症はみられず, $30 〜 60$ 歳 で約 $20 \%$ に発症した。 60 歳以上の提供者でも高血圧の 発症は $33.3 \%$ であった。

\section{6. 固有腎摘除術施行症例}

腎移植後に高血圧が持続し，降圧剂に抵抗を示す 6 例に固有腎摘除術を行なった(表 7 ). CsA 使用例が 5 例で，症例 6 に対しては両側固有腎動脈塞栓術を施行 した. 末梢血 PRA は 5 例で高值を示し, 静脈血サンプ リングにより全例で固有腎からのレニン分泌六進が確 かめられた。また，症例 1 では動脈造影で軽度の移植 腎動脈狭窄も確認された。術後も降圧剂を必要とする 症例が 5 例あるが，血圧は189.6 $222.1 / 113.0 \pm 10.1$ $\mathrm{mmHg}$ から $138.0 \pm 12.8 / 70.3 \pm 9.2 \mathrm{mmHg}$ に低下し， 全例で満足できる降圧効果が得られた。

腎移植後の合併症として高血圧の頻度は比較的高 く，われわれの施設でも CsA 非使用例で $26.7 \%$, CsA 使用例で $56.3 \%$ が高血圧を発症し，移植腎の長期予 後6)や心血管系におよぼす影響を考えると無視できな い発症率と思われる。しかし，腎移植後高血圧の原因 は単一でなく，個々の症例に最適な管理を行なう必要 がある。

腎移植後比較的早期の高血圧は, 提供者の管理法,
腎摘出手技，腎保存法，移植手術手技，阻血時間，免 疫抑制剂，急性拒絶反応などに影響され発症するが7), 移植腎機能の安定にともない $2 \sim 3$ カ月のらちに改善 することが多い，一方，腎不全患者も種々の原因によ り高血圧を合併していることが多く7)，水分管理が不 十分な体液量依存性の高血圧は腎移植により改善され る。しかし，腎移植前の高血圧が長期にわたり，動脈 の器質的変化が強い時は腎移植後も高血圧の改善は期 待できず，このような高血圧はむしろ慢性腎不全ある いは透析療法の合併症と考号られる，われわれの症例 でも，腎移植前の血圧が術後血圧に反映される傾向を 認め, 移植後高血圧が改善する症例は問題にならない が，移植後数カ月を経ても高血圧が持続する症例は， 原因検索や適切な治療を要した。

急性拒絶反応時にはステロイドの大量投与により， また慢性拒絶反応，腎炎再発により，水分・電解質の 排泄障害が原因の体液量依存性高血圧が発症する7). また, 移植腎機能安定時は尿細管機能は正常であるが, 種々の原因により尿細管障害が生じる可能性があり, 腎尿細管性酸血症はよく経験される ${ }^{7) 8}$ ，尿細管・糸球 体フィードバック機構により糸球体濾過率 (GFR) が 調節され高血圧の発症に関与するが，固有腎の有無に より反応が異なり，移植腎以外に腎が存在しない場合 は，遠位尿細管の $\mathrm{NaCl}$ 濃度が高くても GFR が保た れる。

レニン・アンギオテンシン系の関与も腎移植後高血 圧で重要と考えられる3147799. 腎機能が安定していると レニン分泌の調節は正常に保たれる。レニン分泌充進 は拒絶反応や系球体病変の進行による腎血流障害でも 生じるが7), 固有腎や腎動脈狭窄による移植腎からの 


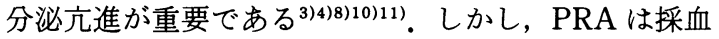
条件, 食塩摄取量, $\mathrm{CsA}^{12113)}$ など種々の要因に影響され るため, 測定値の判断には注意を要する。 さらに, 固 有腎の有無により Goldblatt の 1 腎あるいは 2 腎モデ ルに相当する変化を示すため ${ }^{7) 10)}$, 高血圧症例でも PRA が必ずしも高值を示さない症例がみられいっそ ら複雑となる。しかし，われわれの経験からも，固有 腎を有する症例の静脈血サンプリングは，固有腎，移 植腎のどちらからレニンが分泌されているのかを確か めるためには有効であった。腎動脈狭窄はわれわれの 症例では 1 例に確認されたが，発症率は 1 ～25\%とさ れている ${ }^{10)}$. 腎摘操作, 動脈吻合手技, 動脈のねじれ, 屈曲に注意することは言らまでもなく，手術は慎重に 行なわれねばならないが，慢性拒絶反応によっても狭 窄が生じる711011). バルンによる動脈払張術が第 1 選択 とされているが14), 観血手術が必要になることもある。 固有腎の影響も大きく，降圧剂不応性の移植後高血圧 症例に固有腎摘を行なった報告は多(、344)69915)。われわ れの経験からも，移植時に固有腎摘を行なった症例は 高血圧を発症しないことが多く，また降圧剤でコント ロールが困難であった症例は，固有腎摘により血圧が 安定した。固有腎摘は高血圧の有効な治療法で ${ }^{10)}$, われ われは経カテーテル動脈塞栓術でも同様の効果を得,

侵襲の少ないことを考劣ると試みるべき方法と思われ た。 レニン・アンギオテンシン系が関与すると考学ら れる高血圧は，PRAによる評価が必要とされるが，あ まり重要視していない報告もある4).一般的には，移植 腎と固有腎の両方を有する場合，食塩制限下の saralasin 試験で降圧が得られれば，レニン分泌が固有腎 からか移植腎からかを決定後，適切な治療で効果が期 待できると考えられる9 .

現在 CsA は移植症例のほとんど全例に使用されて いるが，腎毒性によると思われる高血圧がみられ

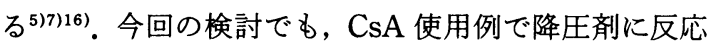
しにくい高血圧が18例にみられた。 この時の CsA 投与 量は4 $5 \mathrm{mg} / \mathrm{kg} /$ 日で血中濃度も高値ではなかった が，われわれは CsA 投与量をさらに減少し，AZ ある いは MZを十分量投与する免度抑制法に変更した。こ の結果血圧のコントロールは比較的容易となり，さら に, クレアチニン上昇傾向を認めていた 12 例中 5 例で クレアチニンは低下し， 3 例で安定化した，維持量の ステロイドは血圧に対する影響が少ないといら報告2) や，術前正常血圧症例のらち移植後高血圧を発症した 症例はI 群で少なく, II 群で多かったことを考えると，
免疫抑制剂減量による血圧の低下は, Pred ๖り CsA の減量効果が大きいものと推察され，血中濃度が低く てもCsA の腎毒性が発生していたと考えられる.CsA は尿細管8) と腎循環に作用して腎毒性を惹起すると考 えられている，腎血管抵抗が上昇するため腎血流の減 少, GFR の低下が括こり ${ }^{17)}, \mathrm{CsA}$ の交感神経系に対す る直接刺激作用もとの機序として考兄られている ${ }^{13)}$. また，CsA は緻密斑を刺激し，尿細管・系球体フィ一 ドバック機構を介して GFR を低下させる作用も有す る ${ }^{18)}$. CsA による高血圧は先ず CsA の減量を考慮す ベきで，これによりクレアチニンの改善とともに血圧 も安定することが多い199.ささらに，われわれが第 1 選択 として使用したカルシゥム拮抗剤が CsA による腎血 管收縮を抑制することが報告され201 22), 降圧剤として の使用とともにCsA の腎毒性予防効果も期待される.

\section{結語}

われわれの経験をもとに，腎移植後高血圧の成因， 管理法を検討し考察を加えた。高血圧は多様な要因が 影響して発症し，長期予後を考えると適切な治療を必 要とする．拒絶反応や腎炎再発の可能性も考慮しなが ら, 先ずカルシウム拮抗剤を中心とした降圧剤の投与, CsA を減量した多剂併用免疫抑制法への変更を行 なった。十分な降圧の得られない症例に対しては, 移 植腎動脈狭窄や固有腎の影響も考慮して検査を進め, 適応症例には動脈塞栓術も含めた固有腎摘除術を行な い良好な結果を得た。

\section{文献}

1) Cohen, S.L.: Hypertension in renal transplant recipients: Role of bilateral nephrectomy. Br. Med. J., 14, 78-81, 1973.

2) Bachy, C., Alexandre, C.P.J. and van Ypersele de Strihou, C.: Hypertension after renal transplantation. Br. Med. J., 27, 1287-1289, 1976.

3) Mchugh, M.I., Tanboga, H., Marcen, R., Liano, F., Robson, V. and Wilkinson, R.: Hypertension following renal transplantation: The role of the host's kidneys. Q. J. Med., 49, 395-403, 1980.

4) Curtis, J.J., Lucas, B.A., Kotchen, T.A. and Luke, R.G.: Surgical therapy for persistent hypertension after renal transplantation. Transplantation, 31, 125-128, 1981.

5）安村忠樹, 大森吉弘, 相川一郎, 吉村了勇, 中井一 郎, 松井 英, 浜島高忠, 李 哲柱, 岡 隆宏：高 血圧を発症したシクロポリン使用腎移植症例の検 討。移植，22，379-383，1987.

6）安村忠樹, 岡 隆宏, 大森吉弘, 相川一郎, 吉村了 
勇, 中井一郎, 松井 英, 浜嶋高志, 李 哲柱, 朴 禹培, 文澈：腎移植後高血圧に対する自己腎 摘出の降圧効果之長期予後. 移植, 22, 160-166, 1987.

7) Sagalowsky, A.I.: Mechanism of posttransplant hypertension. World J. Urol., 7, 102-110, 1989.

8) Stahl, R.A.K., Kanz, L., Maier, B. and Schollmeyer, P.: Hyperchloremic metabolic acidosis with high serum potassium in renal transplant recipients: A cyclosporine $\mathrm{A}$ associated side effect. Clin. Nephrol., 25, 245-248, 1986.

9) Linas, S.L., Miller, P.D., McDonald, K.M., Stables, D.P., Katz, F., Weil, R. and Schrier, R.W. : Role of the renin-angiotensin system in posttransplantation hypertention in patients with multiple kidneys. N. Engl. J. Med., 26, 1440-1444, 1978.

10) Sagalowsky, A.I. and Peters, P.C.: Renovascular hypertension following renal transplantation. Urol. Clin. North Am., 11, 491-502, 1984.

11) Henning, P.H., Bewick, M., Reidy, J.F., Rigden, S.P.A., Neild, G.H. and Chantler, C.: Increased incidence of renal transplant arterial stenosis in children. Nephrol. Dial. Transplant., 4, 575-580, 1989.

12) Bantle, J.P., Nath, K.A., Sutherland, D.E.R., Najarian, J.S. and Ferris, T.F.: Effect of cyclosporine on the renin-angiotensinaldosterone system and potassium excretion in renal transplant recipients. Arch. Int. Med., 145, 505-508, 1985.

13) Murray, B.N., Paller, M.S. and Ferris, T.F.: Effect of cyclosporine administration on renal hemodynamics in conscious rats. Kidney. Int., 28, 767-774, 1985.

14) Sniderman, K.W., Sprayregen, S., Sos, T.A., Saddekn, S., Hilton, S., Mollenkopf, F., Soberman, R., Cheigh, J.S., Tapi, L., Stubenbord, W. Jr., Tellis, V. and Veit, F.J.: Percutaneous transluminal dilation in renal transplant arterial stenosis. Transplantation, 30, 440-444,
1980.

15）栗田 孝, 八竹 直, 秋山隆弘, 門脇照雄, 南 光 二, 井口正典, 郡健二郎, 金子茂男, 園田孝夫, 佐 川史郎, 宇佐美道之, 有馬正明：同種腎移植におけ る自己患腎摘除の意義. 日泌尿会誌, 68, 1224-1250, 1977.

16) Curtis, J.J.: Hypertension after renal transplantation: Cyclosporine increases the diagnostic and therapeutic considerations. Am. J. Kidney Dis., 13, 28-32, 1989.

17) Humes, H.D., Jackson, N.M., O'Connor, R.P., Hunt, D.A. and White, M.D.: Pathogeneic mechanisms of nephrotoxicity: Insights into cyclosporine nephrotoxicity. Transplant. Proc., 17, 51-62, 1985.

18) Bennett, W.M.: Basic mechanisms and pathophysiology of cyclosporine nephrotoxicity. Transplant. Proc., 17, 297-302, 1985.

19）松浦 健, 池上雅久, 今西正昭, 西岡 伯, 石井徳 味, 植村匡志, 国方聖司, 神田英憲, 秋山隆弘, 栗 田孝：cyclosporineを用いた多剤併用による腎 移植免废抑制法の検討. 移植. (受理).

20) Rooth, P., Dawidson, I., Diller, K. and Täljedal, I.-B. : Protection against cyclosporine-induced impairment of renal microcirculation by verapamil in mice. Transplantation, 45, 443-437, 1988.

21) Dawidson, I., Rooth, P., Fisher, D., Fry, W.R., Alway, C., Coorpender, L. and Reisch, J.: Verapamil ameliorates acute cyclosporine A (CsA) nephrotoxicity and improves immunosuppression, after cadaver renal transplantation. Transplant. Proc., 21, 1511-1513, 1989.

22) Marales, J.M., Andre's, A., Prieto, C., Ortuño, B., Estenoz, J., Dorado, C., Arenas, J., Ruilope, L.M., Fernández-Cruz, L. and Rodicio, J.L.: Calcium antagonist treatment of recipients minomizes early cyclosporine nephrotoxicity in renal transplantation: A prospective randomized trial. Transplant. Proc., 21, 1537-1539, 1989.

（1990年 8 月 9 日受理） 